\title{
Synthesis and in vitro anti-HIV-1 evaluation of some $\mathrm{N}$-arylsulfonyl-3-formylindoles
}

\author{
Zhiping Che, Yuee Tian, Shengming Liu, Mei Hu, Genqiang Chen* \\ Laboratory of Pharmaceutical Design \& Synthesis, Department of Plant Protection, College of Forestry, Henan University of \\ Science and Technology, Luoyang, Henan Province, People's Republic of China
}

\begin{abstract}
As our ongoing work on research of anti-HIV-1 inhibitors, fifteen $N$-arylsulfonyl-3-formylindoles (3ao) were designed and prepared through two step synthetic route. Firstly, 3-formylindoles (2a-c) were synthesized via the Vilsmeier-Haack reaction. Subsequently, treatment of $\mathbf{2 a - c}$ with the appropriate arylsulfonyl chlorides led to the corresponding target compounds in excellent yields. All analogues were also preliminary evaluated in vitro for their inhibitory activity against HIV-1 replication. Among of all the reported analogues, three compounds $\mathbf{3 c}, \mathbf{3 g}$ and $\mathbf{3 i}$ displayed significant anti-HIV-1 activity, with $\mathrm{EC}_{50}$ values of $9.57,11.04$ and $5.02 \mu \mathrm{M}$, and TI values of $31.89,13.79$ and 81.69 , respectively. $N-m$ nitrophenylsulfonyl-3-formylindole (3c) and $N$-m-nitrophenylsulfonyl-6-methyl-3-formylindole (3i) especially exhibited the best promising anti-HIV-1 activity. In addition, it demonstrated that insertion of a methyl group at the C-6 position of the indolyl ring and a nitro group at the meta position of the arylsulfonyl ring, as in compound $3 \mathbf{i}$, resulted in both low cytotoxicity $\left(\mathrm{CC}_{50}=410.41 \mu \mathrm{M}\right)$ and good antiviral activity.
\end{abstract}

Keywords: $N$-Arylsulfonyl-3-formylindole/synthesis. Human immunodeficiency virus type-1/inhibitor.

\section{INTRODUCTION}

Acquired immune deficiency syndrome (AIDS) is usually caused by human immunodeficiency virus type 1 (HIV-1) infection and pandemic continues to be a global problem for public health (Faria et al., 2014; Piot, Quinn, 2013; Sampériz et al., 2014). According to Joint United Nations Programme on AIDS (UNAIDS)-2015 report, it is estimated that, approximately 36.9 million people (2.6 million of them were children) were living with HIV infection, and 1.2 millions died due to the infected with HIV and related diseases in the year 2014 (Chander et al., 2016; Global HIV and AIDS Statistics, 2015).

The reverse transcriptase (RT) of the HIV-1 plays a pivotal role in the viral replication process, which makes it a crucial target for anti-HIV-1 inhibitors research (Jonckheere, Anné, De Clercq, 2000; Yisma et al., 2014). In spite of numerous RT inhibitors (including the nucleotide RT inhibitors (NRTIs) and non-nucleotide RT

*Correspondence: G. Q. Chen. Laboratory of Pharmaceutical Design \& Synthesis, Department of Plant Protection, College of Forestry, Henan University of Science and Technology, Luoyang 471003, Henan Province, People's Republic of China. Tel./fax: +86-0379-69978303. E-mail address: genqiangchen@126.com. inhibitors (NNRTIs) have been discovered and developed, like other anti-HIV-1 inhibitors, effectiveness of currently approved NRTIs and NNRTIs have been hampered because of their severe side effects and the aggravation of viral variants resistant to HIV-1 drug (Boone, 2006; De Clercq, 2002; Sluis-Cremer, Wainberg, Schinazi, 2015; Yu et al., 2011). To circumvent this challenge, there is an urgent require to develop new, efficacy, selective and safe HIV-1 inhibitors having significant potency against drugresistant RT viral strains and less toxicity still remains a high priority for medical research (Huang et al., 2007; Polanski et al., 2006; Safakish et al., 2017).

To the best of our knowledge, $N$-arylsulfonylindoles or $N$-arylsulfonyl-3-acylindoles are excellent candidates for the study of serotonin 5- $\mathrm{HT}_{6}$ receptor (Pullagurla et al., 2005; Russell et al., 2001; Tsai et al., 2000) or anti-HIV-1 inhibitors (Che et al., 2016; Fan et al., 2009; Ran et al., 2010), and especially some $N$-arylsulfonyl-3-acetylindoles showed potent anti-HIV-1 activity. The general structural formula of $\mathrm{N}$-arylsulfonylindoles and $\mathrm{N}$-arylsulfonyl3 -acylindoles (Figure 1) is shown as a formula I-III. Nevertheless, no attention has been paid to the anti-HIV-1 activity of the $N$-arylsulfonyl-3-formylindoles. Inspired by 


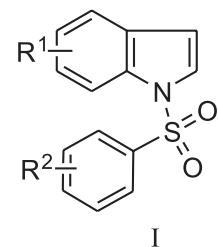

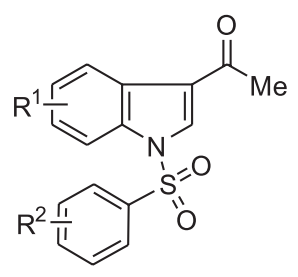

II<smiles>[R1]c1ccc(S(=O)(=O)n2cc(C(=O)CC)c3cc[R1]cc32)cc1</smiles>

III

FIGURE 1 - Chemical structure of $N$-arylsulfonylindoles (I), $N$-arylsulfonyl-3-acetylindoles (II) and $N$-arylsulfonyl-3propionylindoles (III).

these previous observations, and the aim in our program is to discover and develop novel compounds with potent biological activity (Che et al., 2013a; Che et al., 2015; Che et al., 2013b), we report here the results of the synthesis and anti-HIV-1 activity of $15 \mathrm{~N}$-arylsulfonyl-3formylindole derivatives. Furthermore, an investigation of preliminary structure activity relationship (SAR) was also discussed in detail.

\section{RESULTS AND DISCUSSION}

\section{Chemistry}

$\mathrm{N}$-arylsulfonyl-3-formylindoles 3a-o (Figure 2) were prepared using two step synthetic route, reaction conditions used for the synthesis of fifteen target compounds are outlined in Scheme 1. Firstly, treatment of commercially available indoles (1a-c) with $N$, $N$-dimethylformamide (DMF) solution in phosphorus oxychloride $\left(\mathrm{POCl}_{3}\right)$ provided an iminium intermediate, which followed by basic hydrolysis with $30 \%$ aqueous sodium hydroxide $(\mathrm{NaOH})$ afforded 3-formylindoles (2a-c) (Ge, Wu, Xue, 2006). Secondly, introduction of the arylsulfonyl moieties were performed by reacting 2a-c with the appropriate arylsulfonyl chlorides in the presence of potassium carbonate $\left(\mathrm{K}_{2} \mathrm{CO}_{3}\right)$ to produce the corresponding target compounds (3a-0) in excellent yields (Abid, Teixeira, Torok, 2007). Compounds 2a-c, 3a-e, $\mathbf{3 g}-\mathbf{j}, \mathbf{3 l}$ and $\mathbf{3 n}$ were known compounds and characterized by comparison of the data as described in our previous paper (Che et al., 2013b).

\section{Biological activities}

Purified and characterized 3-formylindoles (2a-c) and $\mathrm{N}$-arylsulfonyl-3-formylindoles (3a-0) were screened in vitro for their inhibitory activity against HIV-1 replication in acutely infected C8166 cells, and 3'-azido-<smiles>COc1ccc(S(=O)(=O)n2cc(C=O)c3cc(C=O)cn32)cc1</smiles><smiles>O=Cc1cn(S(=O)(=O)c2cccc([N+](=O)[O-])c2)c2ccccc12</smiles><smiles>O=Cc1cn(S(=O)(=O)c2ccc(Cl)cc2)c2ccccc12</smiles><smiles>O=Cc1cn(S(=O)(=O)c2ccc(Cl)c([N+](=O)[O-])c2)c2ccccc12</smiles><smiles>O=Cc1c[nH]c2ccccc12</smiles><smiles>CS(=O)(=O)c1ccc(Br)cc1</smiles><smiles>Cc1ccc2c(C=O)c[nH]c2c1</smiles><smiles>CCCCN(C)S(=O)(=O)c1ccc(C)cc1</smiles><smiles>COc1ccc(S(=O)(=O)n2cc(C=O)c3ccc(C)cc32)cc1</smiles><smiles>Cc1ccc2c(C=O)cn(S(=O)(=O)c3cccc([N+](=O)[O-])c3)c2c1</smiles><smiles>Cc1ccc2c(C=O)cn(S(=O)(=O)c3ccc(Cl)cc3)c2c1</smiles><smiles>Cc1ccc(S(=O)(=O)n2cc(C=O)c3cc(C=O)ccc32)cc1</smiles><smiles>COc1ccc(S(=O)(=O)n2cc(C=O)c3cc(C#N)ccc32)cc1</smiles><smiles>N#Cc1ccc2c(c1)c(C=O)cn2S(=O)(=O)c1cccc([N+](=O)[O-])c1</smiles><smiles>N#Cc1ccc2c(c1)c(C=O)cn2S(=O)(=O)c1ccc(Cl)c([N+](=O)[O-])c1</smiles>

FIGURE 2 - Chemical structures of $N$-arylsulfonyl-3-formylindoles 3a-o. 

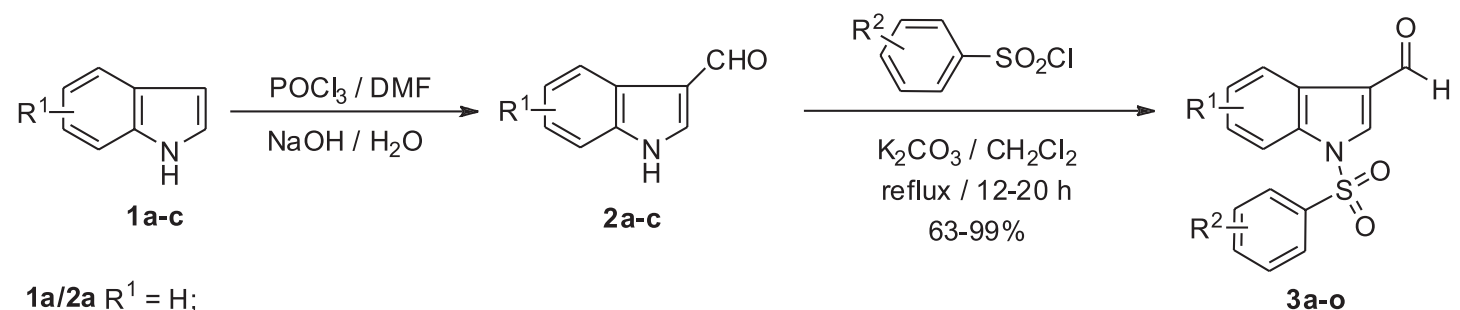

$$
\begin{aligned}
& 1 \mathrm{a} / 2 \mathrm{a} \mathrm{R}^{1}=\mathrm{H} \\
& 1 \mathrm{~b} / 2 \mathrm{~b} \mathrm{R}^{1}=6-\mathrm{Me} ; \\
& 1 \mathrm{c} / 2 \mathrm{c} \mathrm{R}^{1}=5-\mathrm{CN} .
\end{aligned}
$$

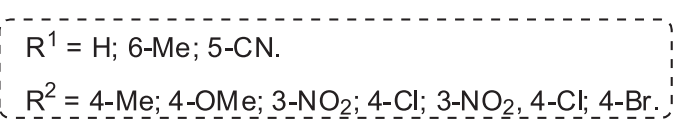

SCHEME 1 - Synthetic route for the preparation of 3-formylindoles (2a-c) and $N$-arylsulfonyl-3-formylindoles 3a-0.

3'-deoxythymidine (AZT) was used as a positive control (see Table I). The results of anti-HIV-1 activity detection revealed that, out of 15 screened $N$-arylsulfonyl-3formylindoles, one (3i) displayed the most significant (effective concentration causing $50 \%$ inhibition of syncytia formation $\left(\mathrm{EC}_{50}\right)$ values of $5.02 \mu \mathrm{M}$, therapeutic index (TI) values of 81.69), two (3c and $\mathbf{3 g}$ ) showed moderate $\left(\mathrm{EC}_{50}\right.$ values of 9.57 and $11.04 \mu \mathrm{M}$, TI values of 31.89 and 13.79 , respectively), while the rest of tested compounds exhibited relatively weak HIV-1 inhibitory activity $\left(\mathrm{EC}_{50}\right.$ values of 11.70 to $46.67 \mu \mathrm{M}$, except $3 \mathrm{e}$, the $\mathrm{EC}_{50}$ values of $7.90 \mu \mathrm{M}$, and TI values of 0.59 to 9.89 ).

Consequently, based upon the above investigation, when the arylsulfonyl moieties were introduced on the 1-position of the indole's ring, the anti-HIV-1 activity of the corresponding compounds were significantly increased (2a $v s$ 3a-f; 2b $v s$ 3g-k; 2c $v s$ 3l-o). For example, the $\mathrm{EC}_{50}$ value of $2 \mathbf{a}\left(\mathrm{EC}_{50}=454.19 \mu \mathrm{M}\right)$ was close to 21 times of that of $\mathbf{3} \mathbf{c}\left(\mathrm{EC}_{50}=9.57 \mu \mathrm{M}\right)$, the TI value of $\mathbf{3 c}(\mathrm{TI}=31.89)$ was more than 16 times of that of $\mathbf{2 a}(\mathrm{TI}=1.96)$; the $\mathrm{EC}_{50}$ value of $\mathbf{2} \mathbf{b}\left(\mathrm{EC}_{50}=428.50 \mu \mathrm{M}\right)$ was more than 39 times of that of $\mathbf{3 i}\left(\mathrm{EC}_{50}=5.02 \mu \mathrm{M}\right)$, the TI value of $\mathbf{3 i}(\mathrm{TI}=81.69)$ was close to 134 times of that of $\mathbf{2} \mathbf{b}(\mathrm{TI}=0.61)$; the $\mathrm{EC}_{50}$ value of $2 \mathbf{c}\left(\mathrm{EC}_{50}=480.35 \mu \mathrm{M}\right)$ was more than 6 times of that of $3 \mathbf{n}\left(\mathrm{EC}_{50}=37.63 \mu \mathrm{M}\right)$, the TI value of $3 \mathbf{n}(\mathrm{TI}=8.94)$ was more than 9 times of that of $\mathbf{2 c}(\mathrm{TI}=0.97)$.

In order to elucidate the HIV-1 inhibitory activity of 3a-o on a molecular level as well as to disclose structural features critical for their activity, an investigation of preliminary structure activity relationship (SAR) was determined in detail, which revealed that the electronic effect of various substituted on $N$-arylsulfonyl-3formylindoles were related to HIV-1 inhibitory activity. In general, (1) Introducing an electron-withdrawing group (such as a nitro group) on the arylsulfonyl ring, could result in the more potent compound than the corresponding one having an electron-donating group (such as a methyl or methoxyl group) (3c vs $\mathbf{3} \mathbf{a}$ and $\mathbf{3 b} ; \mathbf{3 i}$ is $\mathbf{3} \mathbf{g}$ and $\mathbf{3 h} ; \mathbf{3} \mathbf{n} v s$ $\mathbf{3 l}$ and $\mathbf{3 m}$ ). For example, the $\mathrm{EC}_{50}$ and $\mathrm{TI}$ values of $\mathbf{3 c}, \mathbf{3} \mathbf{a}$

\begin{tabular}{|c|c|c|c|}
\hline Compounds & $\mathrm{CC}_{50}^{\mathrm{b}}(\mu \mathrm{M})$ & $\mathrm{EC}_{50}{ }^{\mathrm{c}}(\mu \mathrm{M})$ & $\mathbf{T I}^{\mathrm{d}}$ \\
\hline $2 a$ & 889.79 & 454.19 & 1.96 \\
\hline $3 \mathbf{a}$ & 98.15 & 13.66 & 7.18 \\
\hline $3 b$ & 43.48 & 11.70 & 3.72 \\
\hline $3 c$ & 305.04 & 9.57 & 31.89 \\
\hline 3d & 308.04 & 31.15 & 9.89 \\
\hline $3 e$ & 12.12 & 7.90 & 1.53 \\
\hline $3 f$ & 80.67 & 11.23 & 7.18 \\
\hline $2 \mathrm{~b}$ & 260.89 & 428.50 & 0.61 \\
\hline $3 g$ & 152.22 & 11.04 & 13.79 \\
\hline $3 \mathrm{~h}$ & 196.62 & 41.99 & 4.68 \\
\hline $3 \mathbf{i}$ & 410.41 & 5.02 & 81.69 \\
\hline $3 \mathbf{j}$ & 77.02 & 11.62 & 6.63 \\
\hline $3 \mathrm{k}$ & 13.31 & 9.13 & 1.46 \\
\hline $2 c$ & 465.54 & 480.35 & 0.97 \\
\hline 31 & 194.51 & 39.93 & 4.87 \\
\hline $3 m$ & 151.37 & 32.88 & 4.60 \\
\hline $3 n$ & 336.51 & 37.63 & 8.94 \\
\hline 30 & 27.40 & 46.67 & 0.59 \\
\hline $\mathbf{A} \mathbf{Z} \mathbf{T}^{\mathrm{e}}$ & 4263.82 & 0.01212 & 351688.27 \\
\hline
\end{tabular}

TABLE I - Anti-HIV-1 activity of $n$-arylsulfonyl-3-formylindoles 3a-o in vitro ${ }^{\mathrm{a}}$

${ }^{a}$ Values are means of two separate experiments (the values exhibited standard deviation (SD) less than $\pm 5 \%$ from mean). ${ }^{\mathrm{b}} \mathrm{CC}_{50}(50 \%$ cytotoxic concentration), concentration of drug that causes $50 \%$ reduction in total $\mathrm{C} 8166$ cell number. ${ }^{\mathrm{c}} \mathrm{EC}_{50}(50 \%$ effective concentration), concentration of drug that reduces syncytia formation by $50 \%$. ${ }^{\mathrm{d}}$ In vitro therapeutic index $\left(\mathrm{CC}_{50}\right.$ value / $\mathrm{EC}_{50}$ value). ${ }^{\mathrm{e}} \mathrm{AZT}$ was used as a positive control.

and $\mathbf{3 b}$ were $9.57,13.66,11.70 \mu \mathrm{M}$, and $31.89,7.18,3.72$, respectively; that is, the TI value of $\mathbf{3} \mathbf{c}$ was more than 8 times of that of $\mathbf{3 b}$ and was more than 4 times of that of $\mathbf{3 a}$. The $\mathrm{EC}_{50}$ and TI values of $\mathbf{3 i}, \mathbf{3} \mathbf{g}$ and $\mathbf{3 h}$ were 5.02, 11.04, $41.99 \mu \mathrm{M}$, and $81.69,13.79,4.68$, respectively; that is, the 


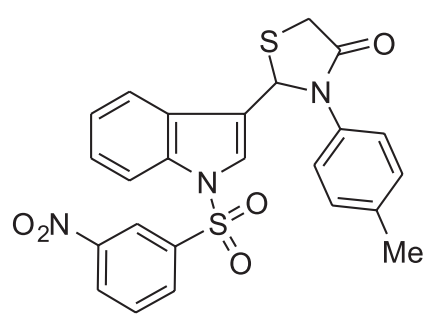

4

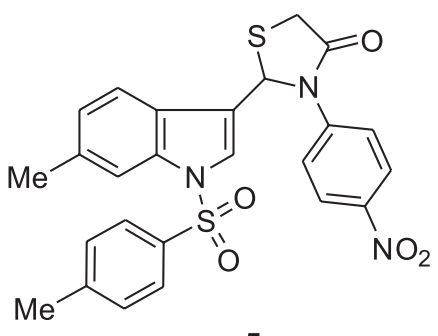

5

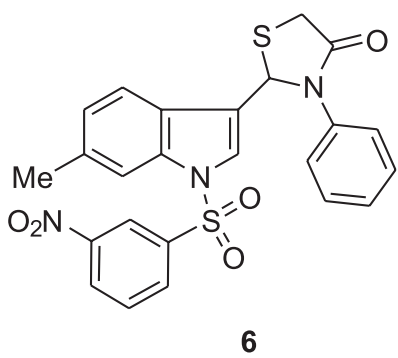

FIGURE 3 - Chemical structure of 2-( $N$-m-nitrophenylsulfonylindol-3-yl)-3-p-methylphenyl-1,3-thiazolidin-4-ones (4), 2-( $N$-pmethylphenylsulfonyl-6-methylindol-3-yl)-3-p-nitrophenyl-1,3-thiazolidin-4-ones (5) and 2-( $N$ - $m$-nitrophenylsulfonyl-6methylindol-3-yl)-3-phenyl-1,3-thiazolidin-4-ones (6).

TI value of $\mathbf{3 i}$ was more than 17 times of that of $\mathbf{3 h}$ and was close to 6 times of that of $\mathbf{3 g}$. The $\mathrm{EC}_{50}$ and TI values of $\mathbf{3 n}, \mathbf{3 l}$ and $\mathbf{3 m}$ were $37.63,39.93,32.88 \mu \mathrm{M}$, and 8.94, $4.87,4.60$, respectively; that is, the TI value of $\mathbf{3 n}$ was nearly 2 times of that of $\mathbf{3} \mathbf{m}$ and was close to 2 times of that of 3l. (2) Interestingly, variations at the C-4 position of the arylsulfonyl ring outbalance to anti-HIV-1 activities for the corresponding compounds (3a $v s \mathbf{3 b} ; \mathbf{3 g} v s \mathbf{3 h}$; 3I $v s \mathbf{3 m}$; 3d $v s$ 3f). For example, 4-methyl was more significant for the anti-HIV-1 activities than 4-ethyl; 4-chloro was more essential for the anti-HIV-1 activities than 4-bromo. The $\mathrm{EC}_{50}$ and TI values of $\mathbf{3 a}, \mathbf{3 b}, \mathbf{3 g}, \mathbf{3 h}$, 31, 3m, 3d and $\mathbf{3 f}$ were 13.66, 11.70, 11.04, 41.99, 39.93, $32.88,31.15$ and $11.23 \mu \mathrm{M}$, and 7.18, 3.72, 13.79, 4.68, 4.87, 4.60, 9.89 and 7.18, respectively. (3) In contrast, when two electron-withdrawing groups (such as nitro and chloro groups) were introduced on the arylsulfonyl ring, the anti-HIV-1 activities of the corresponding compounds were decreased sharply as compared with those containing one electron-withdrawing group (3e $v_{s} \mathbf{3} \mathbf{c}$ and $\mathbf{3 d} ; \mathbf{3 k} v_{s} \mathbf{3 i}$ and $\mathbf{3 j} ; \mathbf{3 o}$ vs 3n). For example, the $\mathrm{EC}_{50}$ and TI values of 3e, 3k and 3o were 7.90, 9.13, $46.67 \mu \mathrm{M}$, and 1.53, 1.46, 0.59 , respectively; that is, the TI value of $\mathbf{3 c}$ was more than 20 times of that of $\mathbf{3 e}$; the TI value of $\mathbf{3 d}$ was more than 6 times of that of $\mathbf{3 e}$; the TI value of $\mathbf{3 i}$ was close to 56 times of that of $\mathbf{3 k}$; the TI value of $\mathbf{3} \mathbf{j}$ was more than 4 times of that of $\mathbf{3 k}$; the TI value of $\mathbf{3 n}$ was more than 15 times of that of 3o. (4) When a methyl group was introduced at the C-6 position of the indolyl ring, the anti-HIV-1activities of the corresponding compounds were more pronounced than those of the compounds carrying a hydrogen group or a cyano group $(\mathrm{TI}=13.79$ for $\mathbf{3 g} v s \mathrm{TI}=7.18$ for $\mathbf{3 a}$ and $\mathrm{TI}=4.87$ for $\mathbf{3 l}$; $\mathrm{TI}=4.68$ for $\mathbf{3 h} v s \mathrm{TI}=3.72$ for $\mathbf{3 b}$ and $\mathrm{TI}=4.60$ for $\mathbf{3} \mathbf{m}$; $\mathrm{TI}=81.69$ for $\mathbf{3 i} v s \mathrm{TI}=31.89$ for $\mathbf{3 c}$ and $\mathrm{TI}=8.94$ for $3 \mathbf{n}$ ). (5) In the meantime, it is noteworthy that insertion of a methyl group at the C-6 position of the indolyl ring and a nitro group at the meta position of the arylsulfonyl ring, as in compound $\mathbf{3 i}$, resulted in both low cytotoxicity (cytotoxic concentration causing 50\% reduction in total C8166 cell number $\left.\left(\mathrm{CC}_{50}\right)=410.41 \mu \mathrm{M}\right)$ and high antiviral activity $(\mathrm{TI}=81.69)$.

It is noteworthy that introduction of the formyl group at the 3-position of $N$-arylsulfonylindoles could generally lead to the more potent compounds (e.g., $\mathbf{3 c}, \mathbf{3 g}$ and $\mathbf{3 i}$ ) relative to those containing 1,3-thiazolidin-4-ones group (e.g., 4, 5 and 6, Figure 3). The $\mathrm{EC}_{50}$ and TI values of three compounds of containing 1,3-thiazolidin-4-ones group at the 3-position of $N$-arylsulfonylindoles were 172.04, $93.46,47.21 \mu \mathrm{M}$, and $>2.36,>4.20,>8.58$, respectively; that is, the $\mathrm{EC}_{50}$ value of 4 was close to 27 times of that of $\mathbf{3 c}$, the $\mathrm{EC}_{50}$ value of $\mathbf{5}$ was close to 14 times of that of $3 \mathbf{g}$, the $\mathrm{EC}_{50}$ value of $\mathbf{6}$ was more than 13 times of that of 3i (Yang et al., 2012). Therefore, further chemical modifications should be deliberately manipulated so as to exploit more potent inhibitors.

\section{EXPERIMENTAL SECTION}

\section{General information}

Unless specified otherwise, all solvents and reagents were commercially available or purified by standard techniques before use. All reactions were monitored by thin-layer chromatography (TLC) on silica gel plates using silica gel $60 \mathrm{GF}_{254}$ (Qingdao Haiyang Chemical Co., Ltd.). Yields were recorded by purification, and preparative thin-layer chromatography (PTLC) was performed with silica gel plates. Melting points were determined using digital melting-point apparatus (Beijing Tech Instrument Co., Ltd.). Nuclear magnetic resonance spectra (NMR) were recorded on a Bruker Avance DMX $500 \mathrm{MHz}$ instrument (Bruker Daltonik, Bremen, Germany) in $\mathrm{CDCl}_{3}$ or DMSO- $d_{6}\left({ }^{1} \mathrm{H}\right.$ at $500 \mathrm{MHz}$ and ${ }^{13} \mathrm{C}$ at $125 \mathrm{MHz}$ ) using tetramethylsilane (TMS) as the internal standard. Electrospray iontrap mass spectrometry (ESI-TRAP-MSn) was performed on a Bruker ESI-TRAP Esquire 3000 plus mass spectrometry instrument (Bruker Daltonics, San Diego, California, USA). The purities of 
the target compounds were determined by reverse phase high-performanceliquid chromatography (RP-HPLC) recorded on a Shimadzu LC-15C liquid chromatograph [SPD-15C UV-Vis spectrophotometric detector (190-700 $\mathrm{nm})$; Shimadzu, Kyoto, Japan] using a Hypersil ODS $\mathrm{C}_{18}$ column $(5 \mu \mathrm{m}, 4.6 \times 150 \mathrm{~mm})$ as the stationary phase.

\section{Preparation of $\mathbf{N}$-arylsulfonyl-3-formylindoles $(3 a-0)$}

A mixture of DMF $(5 \mathrm{~mL})$ and $\mathrm{POCl}_{3}(0.5 \mathrm{~mL})$ was stirred at $0{ }^{\circ} \mathrm{C}$ for $10 \mathrm{~min}$. A solution of indoles (1a-c, 5 $\mathrm{mmol}$ ) in $2 \mathrm{~mL}$ DMF was added dropwise to the former mixture. After the addition, the mixture was stirred at 35 ${ }^{\circ} \mathrm{C}$ for $1 \mathrm{~h}$, then $100 \mathrm{~mL}$ water was added, followed by the addition of $30 \%$ aqueous $\mathrm{NaOH}$ to adjust the $\mathrm{pH}$ value to 8-9. The mixture was refluxed for $1 \mathrm{~h}$. On cooling, the solution was poured into ice water, and the precipitated product was collected, washed by water, and then washed with a certain amount of petroleum ether until it was pure, monitored by TLC. The pure compounds were dried in vacuum drying chamber to afford 3-formylindoles $\mathbf{2 a - c}$ in excellent yields. Subsequently, a solution of 2a-c ( $1 \mathrm{mmol})$, substituted arylsulfonyl chlorides $(2 \mathrm{mmol})$, and $\mathrm{K}_{2} \mathrm{CO}_{3}(3 \mathrm{mmol})$ in dry acetone/dichloromethane $(10 \mathrm{~mL})$ was refluxed for 12-20 h, till the completion of the reaction as monitored by TLC. The reaction mixture was filtered, and the filtrate was merged, the crude product was purified by PTLC (petroleum ether/ethyl acetate, 1/1) to obtain pure compounds 3a-o in 63-99\% yields, and its purity was $>95 \%$ as measured with RP-HPLC. The typical spectral data of compounds $\mathbf{3 f}, \mathbf{3 k}, \mathbf{3 m}$ and $\mathbf{3 o}$ were as follows.

$N$ - $p$-Bromophenylsulfonyl-3-formylindole (Weng et al., 2007) 3f: Tan solid, Yield $=63 \%$, m.p. $145-147^{\circ} \mathrm{C}$. ${ }^{1} \mathrm{H}$ NMR $\left(500 \mathrm{MHz}, \mathrm{CDCl}_{3}\right) \delta: 10.10(\mathrm{~s}, 1 \mathrm{H}), 8.27$ (d, $J=7.5 \mathrm{~Hz}, 1 \mathrm{H}), 8.19(\mathrm{~s}, 1 \mathrm{H}), 7.93(\mathrm{~d}, J=8.5 \mathrm{~Hz}, 1 \mathrm{H})$, 7.80-7.82 (m, 2H), 7.63-7.65 (m, 2H), 7.37-7.44 (m, 2H). MS (ESI-TRAP-MSn), $m / z(\%): 364\left([\mathrm{M}+\mathrm{H}]^{+}, 100\right)$.

$N$ - $m$-Nitro- $p$-chlorophenylsulfonyl-6-methyl3 -formylindole $3 \boldsymbol{k}$ : Yellow solid, Yield $=73 \%$, m.p. 153-155 ${ }^{\circ} \mathrm{C} .{ }^{1} \mathrm{H}$ NMR $\left(500 \mathrm{MHz}, \mathrm{CDCl}_{3}\right) \delta: 10.08(\mathrm{~s}, 1 \mathrm{H})$, $8.48(\mathrm{~d}, J=2.0 \mathrm{~Hz}, 1 \mathrm{H}), 8.13(\mathrm{~d}, J=8.0 \mathrm{~Hz}, 1 \mathrm{H}), 8.11$ $(\mathrm{s}, 1 \mathrm{H}), 8.02-8.04(\mathrm{~m}, 1 \mathrm{H}), 7.71-7.73(\mathrm{~m}, 2 \mathrm{H}), 7.25(\mathrm{dd}$, $J=8.0 \mathrm{~Hz}, 0.5 \mathrm{~Hz}, 1 \mathrm{H}), 2.52(\mathrm{~s}, 3 \mathrm{H}) .{ }^{13} \mathrm{C} \mathrm{NMR}(125 \mathrm{MHz}$, $\left.\mathrm{CDCl}_{3}\right) \delta: 186.4,148.1,137.5,136.1,135.7,133.0,131.6$, 130.7, 128.3, 125.5, 124.3, 122.7, 119.2, 113.2, 21.5. MS (ESI-TRAP-MSn), $m / z(\%): 377$ ([M-H] $\left.]^{-}, 100\right)$.

$N$ - $p$-Methoxylphenylsulfonyl-5-cyano3 -formylindole $3 \boldsymbol{m}$ : White solid, Yield $=88 \%$, m.p. $238-240^{\circ} \mathrm{C} .{ }^{1} \mathrm{H}$ NMR $\left(500 \mathrm{MHz}, \mathrm{DMSO}-d_{6}\right) \delta: 10.09$ $(\mathrm{s}, 1 \mathrm{H}), 9.06(\mathrm{~s}, 1 \mathrm{H}), 8.50(\mathrm{~s}, 1 \mathrm{H}), 8.18(\mathrm{~d}, J=9.0 \mathrm{~Hz}, 1 \mathrm{H})$, $8.13(\mathrm{~d}, J=9.0 \mathrm{~Hz}, 2 \mathrm{H}), 7.89$ (dd, $J=9.0 \mathrm{~Hz}, 1.5 \mathrm{~Hz}, 1 \mathrm{H})$, $7.18(\mathrm{~d}, J=9.0 \mathrm{~Hz}, 2 \mathrm{H}), 3.83(\mathrm{~s}, 3 \mathrm{H}) \cdot{ }^{13} \mathrm{C} \mathrm{NMR}(125 \mathrm{MHz}$, DMSO- $\left.d_{6}\right) \delta: 199.1,186.1,147.5,139.3,135.2,132.1$, 130.4, 129.0, 127.5, 125.4, 120.7, 118.3, 114.7, 107.4, 56.3. MS (ESI-TRAP-MSn), $m / z(\%): 339$ ([M-H] $\left.]^{-}, 100\right)$. $N$ - $m$-Nitro- $p$-chlorophenylsulfonyl-5-cyano3 -formylindole 3o: Yellow solid, Yield $=76 \%$, m.p. $228-230^{\circ} \mathrm{C} .{ }^{1} \mathrm{H}$ NMR $\left(500 \mathrm{MHz}, \mathrm{DMSO}-d_{6}\right) \delta: 10.10$ $(\mathrm{s}, 1 \mathrm{H}), 9.09(\mathrm{~s}, 1 \mathrm{H}), 8.92(\mathrm{~d}, J=2.0 \mathrm{~Hz}, 1 \mathrm{H}), 8.48-8.50$ $(\mathrm{m}, 2 \mathrm{H}), 8.24(\mathrm{~d}, J=9.0 \mathrm{~Hz}, 1 \mathrm{H}), 8.09(\mathrm{~d}, J=9.0 \mathrm{~Hz}, 1 \mathrm{H})$, 7.91 (dd, $J=8.5 \mathrm{~Hz}, 1.5 \mathrm{~Hz}, 1 \mathrm{H}) .{ }^{13} \mathrm{C}$ NMR $(125 \mathrm{MHz}$, DMSO- $\left.d_{6}\right) \delta: 199.1,186.2,148.0,140.1,136.1,132.5$, 130.3, 129.7, 127.9, 125.4, 119.9, 118.8, 115.1, 107.7. MS (ESI-TRAP-MSn), $m / z(\%): 388\left([\mathrm{M}-\mathrm{H}]^{-}, 100\right)$.

\section{Anti-HIV-1 activity assay}

\section{Cells and virus}

Cell line (C8166) and the laboratory-derived virus $\left(\mathrm{HIV}-1_{\text {IIIB }}\right)$ were obtained from MRC, AIDS Reagent Project, UK. C8166 was maintainedin RPMI-1640 supplemented with $10 \%$ heat-inactivated newborn calf serum (Gibco). The cells used in all experiments were in log-phasegrowth. The $50 \% \mathrm{HIV}-1_{\text {IIIB }}$ tissue culture infectious dose $\left(\mathrm{TCID}_{50}\right)$ in $\mathrm{C} 8166$ cells was determined and calculated by the Reed and Muench method. Virus stocks were stored in small aliquots at $-70{ }^{\circ} \mathrm{C}$.

\section{MTT-based cytotoxicity assay}

Cellular toxicity of 3-formylindoles (2a-c) and $\mathrm{N}$-arylsulfonyl-3-formylindoles (3a-o) on C8166 cells was assessed by MTT method as described previously. Briefly, cells were seeded on 96-well microtiter plate in the absence or presence of various concentrations of $\mathrm{N}$-arylsulfonyl-3-formylindoles in triplicate and incubated at $37{ }^{\circ} \mathrm{C}$ in a humid atmosphere of $5 \% \mathrm{CO}_{2}$ for $3 \mathrm{~d}$. The supernatants were discarded and MTT reagent $(5 \mathrm{mg} / \mathrm{mL}$ in PBS) was added to each wells, then incubated for $4 \mathrm{~h}$, $100 \mu \mathrm{L}$ of $50 \% N, N$-dimethylformamide (DMF)- $20 \%$ SDS was added. After the formazan was dissolved completely, the plates were read on a Bio-TekElx800 ELISA reader at $595 / 630 \mathrm{~nm}$. The cytotoxic concentration that caused the reduction of viable $\mathrm{C} 8166$ cells by $50 \%\left(\mathrm{CC}_{50}\right)$ was determined from dose-response curve.

\section{Syncytia assay}

In the presence of $100 \mu \mathrm{L}$ various concentrations of $\mathrm{N}$-arylsulfonyl-3-formylindoles, C8166 cells $\left(4 \times 10^{5} / \mathrm{mL}\right)$ were infected with virus HIV-1 $1_{\text {IIIB }}$ at a multiplicity of 
infection (M.O.I) of 0.06. The final volume per well was $200 \mu \mathrm{L}$. Control assays were performed without the testing compounds in HIV-1 $1_{\text {IIIB }}$ infected and uninfected cultures. After $3 \mathrm{~d}$ of culture, the cytopathic effect (CPE) was measured by counting the number of syncytia. Percentage inhibition of syncytia formation was calculated and $50 \%$ effective concentration $\left(\mathrm{EC}_{50}\right)$ was calculated. AZT (Sigma) was used as a positive control. Therapeutic index $(\mathrm{TI})=\mathrm{CC}_{50} / \mathrm{EC}_{50}$.

\section{CONCLUSIONS}

In conclusion, fifteen $N$-arylsulfonyl-3formylindoles (3a-o) were prepared and preliminarily evaluated as HIV-1 inhibitors in vitro. Especially, $N$-m-nitrophenylsulfonyl-3-formylindole (3c) and $\mathrm{N}$-m-nitrophenylsulfonyl-6-methyl-3-formylindole (3i) displayed moderate anti-HIV-1 activity with $\mathrm{EC}_{50}$ values of 9.57 and $5.02 \mu \mathrm{M}$, and TI values of 31.89 and 81.69 , respectively. In addition, it demonstrated that introduction of the methyl group at the C-6 position of the indolyl ring and the nitro group at the meta position of the phenylsulfonyl ring were two certainly important functional groups for $3 \mathbf{i}$ being significant anti-HIV-1 activity.

\section{ACKNOWLEDGEMENTS}

The present research was supported by the National Natural Science Foundation of China (Grant No. U1604105), the Doctoral Scientific Research Fund Project of Henan University of Science and Technology (Grant No. 09001763) and Henan Province Natural Science Foundation (Grant No. 162300410079). We would like to acknowledge the MRC AIDS Research Project and the NIH AIDS Research and Reference Reagent Program for providing cell lines and viruses.

\section{CONFLICT OF INTEREST}

The authors have reported no conflict of interest.

\section{REFERENCES}

Abid M, Teixeira L, Torok B. Triflic acid controlled successive annelation of aromatic sulfonamides: an efficient one-pot synthesis of $N$-sulfonyl pyrroles, indoles and carbazoles. Tetrahedron Lett. 2007;48(23):4047-50.
Boone LR. Next-generation HIV-1 non-nucleoside reverse transcriptase inhibitors. Curr Opin Investig Drugs. 2006;7(2):128-35.

Chander S, Wang P, Ashok P, Yang LM, Zheng YT, Murugesan S. Rational design, synthesis, anti-HIV-1 RT and antimicrobial activity of novel 3-(6-methoxy-3,4-dihydroquinolin-1(2H)yl)-1-(piperazin-1-yl) propan-1-one derivatives. Bioorg Chem. 2016;67:75-83.

Che ZP, Huang N, Yu X, Yang LM, Ran JQ, Zhi XY, et al. Microwave-assisted combinatorial synthesis of 2-alkyl-2-( $N$ arylsulfonylindol-3-yl)-3- $N$-acyl-5-aryl-1,3,4-oxadiazolines as anti-HIV-1 agents. Comb Chem High T Scr. 2013a;16(5):400-7.

Che ZP, Liu SM, Tian YE, H, ZJ, Chen YW, Chen GQ. Design and synthesis of novel $N$-arylsulfonyl-3-(2-yl-ethanone)-6methylindole derivatives as inhibitors of HIV-1 replication. Pharmaceuticals. 2015;8(2):221-9.

Che ZP, Tian YE, Hu ZJ, Chen YW, Liu SM, Chen GQ. Synthesis and in vitro anti-HIV-1 activity of a series of $N$-arylsulfonyl-3propionylindoles. Z Naturforsch C. 2016;71(5-6):105-9.

Che ZP, Zhang SY, Shao YH, Fan LL, Xu H, Yu X, et al. Synthesis and quantitative structure-activity relationship (QSAR) study of novel $\mathrm{N}$-arylsulfonyl-3-acylindole arylcarbonyl hydrazone derivatives as nematicidal agents. J Agric Food Chem. 2013b;61(24):5696-705.

De Clercq E. New developments in anti-HIV chemotherapy. Biochim Biophy Acta. 2002;1587(2-3):258-75.

Fan LL, Liu WQ, Xu H, Yang LM, Lv M, Zheng YT. Anti human immunodeficiency virus-1 (HIV-1) agents 3. synthesis and in vitro anti-HIV-1 activity of some $N$-arylsulfonylindoles. Chem Pharm Bull. 2009;57(8):797-800.

Faria NR, Rambaut A, Suchard MA, Baele G, Bedford T, Ward $\mathrm{MJ}$, et al. The early spread and epidemic ignition of HIV-1 in human populations. Science. 2014;346(6205):56-61.

Ge YH, Wu YM, Xue ZJ. Synthesis of substituted indole-3carboxaldehyde derivatives. Chin J Org Chem. 2006;26(4):563-7.

Global HIV and AIDS statistics. [cited 2015 Nov 8]. Available from: http://www.unaids.org/en/resources/campaigns/ HowAIDSchangedeverything/. 
Huang L, Yu DL, Ho P, Lee KH, Chen CH. Synthesis and antiHIV activity of bi-functional triterpene derivatives. Lett Drug Des Discov. 2007;4(7):471-8.

Jonckheere H, Anné J, De Clercq E. The HIV-1 reverse transcription (RT) process as target for RT inhibitors. Med Res Rev. 2000;20(2):129-54.

Piot P, Quinn TC. Global health: response to the AIDS pandemic-a global health model. N Engl J Med. 2013;368(23):2210-8.

Polanski J, Niedbala H, Musiol R, Podeszwa B, Tabak D, Palka A, et al. 5-Hydroxy-6-quinaldic acid as a novel molecular scaffold for HIV-1 integrase inhibitors. Lett Drug Des Discov. 2006;3(3):175-8.

Pullagurla M, Siripurapu U, Kolanos R, Bondarev ML, Dukat M, Setola V, et al. Binding of amine-substituted $N_{1^{-}}$ benzenesulfonylindoles at human $5-\mathrm{HT}_{6}$ serotonin receptors. Bioorg Med Chem Lett. 2005;15(23):5298-302.

Ran JQ, Huang N, Xu H, Yang LM, Lv M, Zheng YT. Anti HIV-1 agents 5: synthesis and anti-HIV-1 activity of some $\mathrm{N}$-arylsulfonyl-3-acetylindoles in vitro. Bioorg Med Chem Lett. 2010;20(12):3534-6.

Russell MGN, Baker RJ, Barden L, Beer MS, Bristow L, Broughton HB, et al. $N$-Arylsulfonylindole derivatives as serotonin 5- $\mathrm{HT}_{6}$ receptor ligands. J Med Chem. 2001;44(23):3881-95.

Safakish M, Hajimahdi Z, Zabihollahi R, Aghasadeghi MR, Vahabpour R, Zarghi A. Design, synthesis, and docking studies of new 2-benzoxazolinone derivatives as anti-HIV-1 agents. Med Chem Res. 2017;26(11): 2718-2726.
Sampériz G, Guerrero D, López M, Valera J, Iglesias A, Ríos Á, et al. Prevalence of and risk factors for pulmonary abnormalities in HIV-infected patients treated with antiretroviral therapy. HIV Med. 2014;15(6):321-9.

Sluis-Cremer N, Wainberg MA, Schinazi RF. Resistance to reverse transcriptase inhibitors used in the treatment and prevention of HIV-1 infection. Future Microbiol. 2015;10(11):1773-82.

Tsai Y, Dukat M, Slassi A, MacLean N, Demchyshyn L, Savage JE, et al. $N_{1}$-(Benzenesulfonyl)tryptamines as novel 5- $\mathrm{HT}_{6}$ antagonists. Bioorg Med Chem Lett. 2000;10(20):2295-9.

Weng JR, Tsai CH, Kulp SK, Wang D, Lin CH, Yang HC, et al. A potent indole-3-carbinol derived antitumor agent with pleiotropic effects on multiple signaling pathways in prostate cancer cells. Cancer Res. 2007;67(16):7815-24.

Yang RG, Yang LM, Ke YZ, Huang N, Zhang R, Zheng YT, et al. Synthesis of new 2-( $N$-arylsulfonylindol-3-yl)-3-aryl-1,3thiazolidin-4-ones as HIV-1 inhibitors in vitro. Lett Drug Des Discov. 2012;9(4):415-20.

Yisma E, Dessalegn B, Astatkie A, Fesseha N, Benagiano G, Bastianelli C, et al. Global report: UNAIDS report on the global AIDS epidemic 2013. Reprod Health. 2014;10:23.

Yu MY, Fan EK, Wu JD, Liu XY. Recent advances in the DABOs family as potent HIV-1 non-nucleoside reverse transcriptase inhibitors. Curr Med Chem. 2011;18(16):2376-85.

Received for publication on $02^{\text {nd }}$ February 2017 Accepted for publication on $09^{\text {th }}$ January 2018 